\title{
NEODREĐENA ZAMENICA ONE U PISANJU KOD NEIZVORNIH GOVORNIKA ENGLESKOG JEZIKA***
}

Neizvorni govornici engleskog jezika u svojim sastavima mešaju formalno, neutralno i neformalno izražavanje, te se istraživanje u ovom radu fokusira na ovo mešanje stilova kroz posmatranje $\mathrm{i}$ analizu neodređene zamenice one $\mathrm{u}$ studentskim sastavima pisanim na engleskom jeziku kao stranom. Analizom korpusa od 325 sastava sakupljenih u četiri univerzitetska centra (Istočno Sarajevo, Banja Luka, Beograd i Novi Sad) došlo se do podatka da se ova neodređena zamenica koristi u 35\% sastava, u kojima se javlja oko 300 puta. S obzirom na to da je neodređena zamenica one jedan od nekoliko mogućih eksponenata ličnog metadiskursa u tekstu, u radu će se posmatrati i učestalost drugih zamenica (I, me, you, we), kako kvantitativno tako i kvalitativno, da bi se potvrdila ili opovrgla hipoteza da u studentskim sastavima pisanim na engleskom jeziku kao stranom dolazi do mešanja izrazito formalnog stila (upotreba neodređene zamenice one) i neutralnog i neformalnog stila (upotreba ličnih zamenica), što je, kako se pretpostavlja, rezultat uticaja nastave u kojoj se naglašava impersonalnost, odsustvo ličnog pečata u pisanju na engleskom jeziku kao stranom.

Ključne reči: akademsko pisanje, neodređena zamenica one, engleski jezik kao strani, korpusna analiza, analiza međujezika.

\footnotetext{
*radic.bojanic@gmail.com, radic.bojanic@ff.uns.ac.rs

** Rad je nastao na osnovu usmenog saopštenja pod nazivom „Bezlična zamenica one u pisanju kod neizvornih govornika engleskog jezika” na naučnom skupu „Nauka i stvarnost”, koji je održan na Filozofskom fakultetu u Palama, u maju 2019. godine. Rad je napisan u okviru projekta Frazeološka kompetencija srpskih govornika engleskog kroz prizmu kontrastivne analize međujezika, koji sufinansira Ministarstvo za naučnotehnološki razvoj, visoko obrazovanje i informaciono društvo Republike Srpske.
} 


\section{UVOD}

Akademsko pisanje je oblast od velikog značaja za tercijarno obrazovanje, pošto se veliki deo zanimanja danas u manjoj ili većoj meri zasniva na pisanoj produkciji (pisanje izveštaja, članaka, predloga projekata, poslovna korespondencija). U okviru studija strane filologije akademsko pisanje zauzima posebno mesto, pošto je ono vrlo često i nastavno sredstvo (za ocenjivanje napretka studenata u kompetencijama na stranom jeziku) i nastavni cilj (neophodna veština koju studenti treba da savladaju da bi mogli da pišu seminarske radove i masterske teze). Međutim, ono što se često primećuje u studentskim akademskim sastavima jeste visok stepen jezičke kompetencije nasuprot nižem stepenu diskursne kompetencije. Drugim rečima, studenti vrlo često u svojim sastavima mešaju formalno, neutralno i neformalno izražavanje, dolazi do transfera osobina srpskog akademskog diskursa na tekst pisan na engleskom jeziku, javlja se čitav niz grešaka pragmatičke prirode itd. Stoga se u ovom radu istraživanje fokusira upravo na prvi predočeni problem, a to je mešanje formalnog i neutralnog izražavanja, i to kroz posmatranje i analizu neodređene zamenice one u 325 sastava pisanih na engleskom jeziku i sakupljenih u četiri univerzitetska centra (Istočno Sarajevo, Banja Luka, Beograd i Novi Sad). S obzirom na to da je neodređena zamenica one jedan od nekoliko mogućih eksponenata ličnog metadiskursa u tekstu, u radu se posmatra $i$ učestalost drugih zamenica ( $I, m e$, you, we), da bi se potvrdila ili opovrgla hipoteza da u studentskim sastavima pisanim na engleskom jeziku kao stranom dolazi do mešanja izrazito formalnog stila (neodređena zamenica one) i neutralnog i neformalnog stila (lične zamenice).

\section{NEODREĐENA ZAMENICA ONE}

Neodređena zamenica one u sistemu engleske gramatike ima dve funkcije: može da zamenjuje imenicu ili imeničku sintagmu pomenutu u rečenici (npr. An artist cannot fail; it is success to be one), ali može i da vrši funkciju generičke referencije, upućujući na ljude uopšteno (npr. Success and acclaim were seen as a means of validating one's existence.) (Quirk, Greenbaum, Leech \& Svartvik, 1991: 387-388; Biber, Johansson, Leech, Conrad \& Finegan, 1999: 353-354). Ova zamenica ima i svoj prisvojni oblik - one's, kao i povratni - oneself, koji takođe imaju zameničku i generičku funkciju (Quirk et al., 1991: 387). Zamenica one neutralna je u pogledu roda (Huddleston \& Pullum, 2002: 427), te je ova neutralnost naročito kvalifikuje za upotrebu u formalnom stilu pisanja. 
Bajber i saradnici (Biber et al., 1999: 354) navode da je generička upotreba ove zamenice i njenog prisvojnog i povratnog oblika karakteristična za bezlični stil, koji se često koristi u akademskim tekstovima. Sem toga, korpusna istraživanja na kojima počiva ova obimna gramatika engleskog jezika pokazala su da je generička upotreba ove zamenice mnogo ređa u odnosu na osnovnu zameničku i da je ograničena samo na pisani registar (Biber et al., 1999: 354); tačnije, najčešće se na nju nailazi u prozi ili u akademskom pisanom diskursu, dok je u govornom diskursu izuzetno retka, a kada se i javi, uglavnom je u pitanju govor britanske više klase.

Informacije u literaturi o učestalosti ove zamenice u akademskom diskursu oprečne su, pošto Bajber i saradnici (Biber et al., 1999) tvrde da je prilično učestala, a Adel (Ädel, 2006) tvrdi da je ima iznenađujuće malo. Međutim, u akademskom diskursu njena bezličnost je svakako odlično sredstvo generalizacije, pošto joj nedostaju lični tonovi, koji se pripisuju drugim zamenicama kada vrše generičku funkciju i upućuju na ljude uopšteno (Biber et al., 1999: 355). Sličnu generičku funkciju u pisanom diskursu vrši i zamenica we, sa čijom se frekvencijom obično poredi frekvencija zamenice one, a obe ove zamenice i njihovi prisvojni i povratni oblici imaju za cilj da u akademskom diskursu postignu uopštavanje argumenata, ciljeva i zaključaka. Razlika između ove dve zamenice leži upravo u prisustvu ličnih tonova, koje je vidljivo kroz upotrebu zamenice we, ili njihovom odsustvu, što se primećuje kod upotrebe zamenice one. Ovo se posledično u akademskom diskursu vidi kao neutralan ili veoma formalan stil pisanja.

Kad se radi o istraživanju akademskog diskursa, neodređena zamenica one u generičkoj funkciji analizira se iz perspektive ličnog metadiskursa, koji Adel (Ädel, 2006) definiše kao jezičke jedinice koje upućuju na prisustvo (glas) pisca i čitaoca u tekstu, koje ukazuju na organizaciju teksta itd. U pitanju je refleksivni model zasnovan na Jakobsonovim elementima govorne situacije, od kojih Adel (Ädel, 2006: 13) uzima tri ključna elementa (govornika, tj. pisca, slušaoca, tj. čitaoca, i jezik) koji učestvuju u izgradnji metadiskursa. U ovom modelu metadiskurs se „određuje kao sveukupnost jezičkih izraza koji se odnose na tekući diskurs, uključujući upućivanje na pisca u ulozi pisca i čitaoca u ulozi čitaoca" (Marković, 2019: 89). Svrha ličnog metadiskursa upravo je obeležavanje interakcije između pisca i čitaoca, mada tu može da se ubroji i tekstualni lični metadiskurs, u kome pisac ilustruje i objašnjava svoju ulogu u izgradnji teksta.

Potrebno je napomenuti da Adel (Ädel, 2006) za neodređenu zamenicu one kaže da je jedan od eksponenata ličnog metadiskursa (koji se generalno oslanja na upotrebu ličnih zamenica). Drugim rečima, ova zamenica može da se odnosi i na pisca teksta, ali i na čitaoca (Ädel, 2006: 82), kao npr. u rečenici „One might argue 
that it is important for the black student to experience their college years in this way" (Ädel, 2006: 85). Pošto je u pitanju neodređena zamenica, ona ne upućuje direktno i eksplicitno (lično) na autora teksta ili na čitaoca, ali svakako upućuje na nekog referenta, osobu koja je prisutna u dijaloškom odnosu pisca, čitaoca i teksta. One na pisca teksta upućuje na indirektan, skriven način, što doprinosi neodređenom stilu akademskog diskursa.

$\mathrm{S}$ obzirom na to da je neodređena zamenica one u generičkoj funkciji ovde opisana kao jedna od osobina akademskog diskursa izvornih govornika engleskog jezika, zanimljivo je istražiti da li i u kojoj meri neizvorni govornici engleskog jezika koriste ovu zamenicu u akademskom pisanju, te da li je upotreba dosledna formalnom stilu, ili pak dolazi do mešanja formalnog i neutralnog stila.

\section{METODOLOGIJA ISTRAŽIVANJA}

Istraživanje $\mathrm{u}$ ovom radu počiva na korpusnoj analizi korpusa ICLE (International Corpus of Learner English, Catholic University of Louvain), koji sadrži veliki broj argumentativnih sastava napisanih na engleskom, čiji su autori neizvorni govornici engleskog jezika. Tačnije, u radu se analizira treća verzija ovog korpusa, koja u sebi sadrži potkorpus argumentativnih sastava čiji su autori izvorni govornici srpskog jezika, a koji Marković (2018) naziva SRBICLE, što je ujedno i naziv koji će se koristiti u ovom radu. Potkorpus SRBICLE sastoji se od 325 argumentativnih sastava koje su pisali studenti engleskog jezika, izvorni govornici srpskog, na četiri univerziteta - Istočno Sarajevo, Banja Luka, Beograd i Novi Sad, pri čemu je dužina svakog sastava oko 500 reči ili više (više podataka o korpusu u Marković, 2019).

U skladu sa principima korpusne analize diskursa i metadiskursa, koje detaljno opisuje Adel (Ädel, 2006), a pominje Hajland (Hyland, 1998), analiza ovog korpusa izvršena je u dva koraka: prvo su uz pomoć besplatnog softvera Antconc iz celokupnog korpusa izvučene konkordanse za zamenicu one, njen prisvojni oblik one's i njenu povratnu formu - oneself, a potom su svi dobijeni rezultati (862 instance) ručno filtrirani da bi se odbacili slučajevi u kojima dobijena reč one nema generičku funkciju neodređene zamenice, već vrši funkciju broja ili zameničku funkciju. Nakon ove dvofazne analize korpusa, dobijena su 302 konteksta u kojima neodređena zamenica one, njen prisvojni oblik - one's i njena povratna forma oneself imaju metadiskursnu funkciju upućivanja na pisca, čitaoca ili obe strane u pisanom diskursu. Tačnije, oblici ove zamenice pronađeni su u 115 sastava od 325, što čini jednu trećinu ukupnog korpusa. 
Pošto se u radu polazi od hipoteze da u studentskim sastavima pisanim na engleskom jeziku kao stranom dolazi do mešanja izrazito formalnog stila (neodređena zamenica one) i neutralnog i neformalnog stila (lične zamenice), navedeni sastavi koji su u sebi sadržavali neki od oblika zamenice one kvantitativno su analizirani da bi se dobio naporedni podatak o broju ličnih zamenica i njihovih oblika koje su autori sastava koristili zajedno sa neodređenom zamenicom one, ali dalja analiza ličnih zamenica nije vršena, pošto je to detaljno već uradila Marković (2017).

Naposletku, bitno je i objasniti značaj analize pisane produkcije neizvornih govornika nekog jezika. Pošto je, kako je rečeno na početku rada, akademsko pisanje značajna veština koja treba da se razvija u okviru tercijarnog obrazovanja, za nastavnike koji rade na razvoju ove veštine od presudnog su značaja dijagnostičke informacije koje ukazuju na slabosti u pisanju studenata i na koje treba da se obrati veća pažnja u nastavnom procesu. Veliku ulogu u ovome igra metodološki pristup koji se naziva analiza međujezika (engl. interlanguage analysis) (npr. Lakshmanan \& Selinker, 2001), i koji se zasniva na hipotezi međujezika (engl. interlanguage hypothesis). Tu hipotezu predložio je Selinker (Selinker, 1972) da bi objasnio karakteristike sistema stranog jezika, koji se delimično razlikuje i od maternjeg jezika učenika i od sistema stranog jezika kad ga govore njegovi izvorni govornici. Informacije o međujeziku daju podatke kako o transferu tako i o interferenciji, ali i ukazuju na problematične oblasti, kojima je potrebno pokloniti više pažnje u nastavnom procesu da bi učenici dostigli što viši nivo jezičke i komunikativne kompetencije na stranom jeziku. Ovo je ujedno i primenjeni ishod ove vrste analize, koja ne daje samo teorijsko-metodološki doprinos nauci, već nalazi i praktičnu primenu u oblasti koja se izučava.

\section{REZULTATI I DISKUSIJA}

Tokom već opisanog postupka korpusne analize korpusa SRBICLE utvrđeno je da se neodređena zamenica one, njen prisvojni oblik - one's i njena povratna forma - oneself koriste 302 puta u 115 sastava (v. Tabelu 1). Drugim rečima, u svakom se sastavu u proseku tri puta upotrebi neki od ova tri oblika neodređene zamenice one, mada kvalitativna analiza otkriva, što će se ilustrovati kasnije, da se u nekim sastavima ova zamenica javlja po jednom, dok se u drugim javlja i po pet-šest puta.

Tabela 1. Učestalost oblika neodređene zamenice one u korpusu SRBICLE

\begin{tabular}{|c|c|c|c|}
\hline one & one's & oneself & ukupno \\
\hline 230 & 47 & 25 & 302 \\
\hline
\end{tabular}


Nadalje, $s$ obzirom na hipotezu o mešanju veoma formalnog i neutralnog/neformalnog stila u pisanju argumentativnih sastava, korpus je kvantitativno analiziran, da bi se dobio podatak o učestalosti oblika ličnih zamenica $^{1}$ (v. Tabelu 2), radi poređenja sa podacima o oblicima zamenice one.

Tabela 2. Učestalost oblika ličnih zamenica u korpusu SRBICLE

\begin{tabular}{|c|c|c|c|c|c|c|c|c|c|c|c|c|}
\hline $\begin{array}{l}\stackrel{0}{0} \\
\stackrel{0}{0}\end{array}$ & - & ミ & झे & 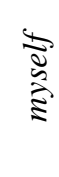 & $\cong$ & $\Xi$ & $\S$ & 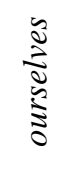 & $\Xi$ & $\stackrel{\Xi}{2}$ & 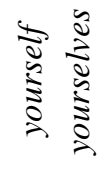 & $\begin{array}{l}\text { Oे } \\
\text { 言 } \\
\text { 亲 }\end{array}$ \\
\hline 70.042 & 243 & 44 & 84 & 8 & 678 & 273 & 182 & 22 & 369 & 106 & 20 & 2029 \\
\hline
\end{tabular}

Kad se porede podaci iz dve tabele, uviđa se da je, na primer, učestalost upotrebe oblika neodređene zamenice one i lične zamenice $I$ veoma slična: 302 slučaja za one i 379 za $I$. Učestalost oblika druge zamenice kojom se signalizira autorsko prisustvo u tekstu, zamenice we i njenih oblika, mnogo je veća (1155 puta). Naposletku, oblici lične zamenice you u korpusu se javljaju ukupno 495 puta.

Pošto je kvantitativna analiza pokazala da u studentskim argumentativnim sastavima autori koriste kako oblike neodređene zamenice one tako i oblike ličnih zamenica u funkciji ličnog metadiskursa, što ukazuje na mešanje veoma formalnog stila, obeleženog upotrebom oblika neodređene zamenice one, i neutralnog, i čak neformalnog stila, obeleženog upotrebom oblika ličnih zamenica, potrebno je uraditi i kvalitativnu analizu, koja će utvrditi na koji način dolazi do ovog mešanja stilova. U te svrhe posmatran je neposredni rečenični kontekst oko oblika neodređene zamenice one i ustanovljeno je da postoji nekoliko pravilnosti u 115 analiziranih sastava.

S jedne strane, utvrđeno je da se u 65 sastava neodređena zamenica one ili neki njen oblik (one's ili oneself) javlja samo po jednom, dok se u ostalim sastavima iz korpusa neki od oblika ove neodređene zamenice javlja više od po jednom. U potonjem slučaju namera je bila da se utvrdi da li se neki od oblika ove

${ }^{1}$ Rezultati koje je dobila Marković (2017) vrlo su slični ovde prikazanim rezultatima, s tim što je njen korpus imao oko 80.000 reči, a ovde analizirani korpus oko 70.000 reči. Poređenja radi, izračunati su procenti zastupljenosti ličnih zamenica u oba korpusa, pa kod Marković (2017) lične zamenice čine oko 4\% korpusa, dok u ovom istraživanju one čine oko $3 \%$ korpusa. 
neodređene zamenice javljaju samo u jednom delu sastava ili u celom sastavu. S druge strane, na rečeničnom nivou utvrđeno je da postoje rečenice u kojima autori koriste samo neki od oblika zamenice one, dok se u rečenicama ispred i/ili iza koriste razni oblici ličnih zamenica. Sem toga, na rečeničnom nivou identifikovane su i rečenice u kojima autori mešaju upotrebu nekog od oblika neodređene zamenice one i oblika ličnih zamenica. Svi ovi konteksti i obrasci ilustrovaće se u nastavku rada i kratko će se objasniti stilski efekat u domenu akademskog pisanja.

Kako je već rečeno, u više od pola sastava neodređena zamenica one ili neki njen oblik javlja se samo po jednom, vrlo često na samom početku sastava, a autori zatim u ostatku teksta koriste neku od ličnih zamenica u funkciji ličnog metadiskursa (v. primere 1, 2 i 3).

One could say it is extremely challenging to find the perfect match or that is to say your soulmate. Little do we know about each other, our emotions and things that affected us most profoundly. [...] But, does it really matter if someone is 10 or 15 older than you? Can you have a great relationship with someone who is much older or much younger than you?

In the age of free love and archaic moral norms, one cannot be certain about rightness of their choice. [...] We could say that they are, more or less, defined personalities in their teenage years $[\ldots]$.

Every scientific breakthrough has the potential to improve our lifestyle and nudge $u s$ ever closer to a world unfathomable to those before $u s$. [...] It has the power to bring the world into your living space through the internet, as well as serve as an entire work desk, accounting team and entertainment centre, all rolled into one. But have we come to rely too much on computers?

We've all heard stories (or experienced them firsthand): [...] One can ascertain from these examples that computers are an integral part of our daily lives.

S druge strane, kad se neodređena zamenica one ili njen prisvojni ili povratni oblik javi u tekstu više puta, nema doslednog obrasca na osnovu kog bi se 
moglo tvrditi da autori koriste ovu zamenicu samo u jednom delu, ili pak svuda, od početka do kraja. Drugim rečima, neodređena zamenica one u korpusu se javlja i u uvodu i u zaključku, ali i u centralnim paragrafima, tako da se ne može utvrditi izvesna pravilnost.

Nadalje, u slučajevima kad se neodređena zamenica one ili neki njen oblik javlja u sastavu više puta, postoje dva obrasca: (a) one se javlja u rečenici zajedno sa drugim zamenicama u funkciji ličnog metadiskursa; (b) neodređena zamenica one sama je u rečenici, ali rečenice ispred i iza koriste razne oblike ličnih zamenica u funkciji ličnog metadiskursa.

Prvi obrazac, po kom se neodređena zamenica one ili neki njen oblik javlja u rečenici naporedo sa drugim zamenicama, pri čemu sve vrše funkciju ličnog metadiskursa, čini se češćim u korpusu (v. primere 4, 5 i 6).

The first of the reasons one could favour the movie adaptation is very trivial, but also quite practical and beloved by students: watching a film adaptation of a book you have to read for whatever reason, but you can't find the time or the strength of will, perhaps because the book is horrible and tedious, like "Ivanhoe" for example.

And if you do happen to watch the movie adaptation first, one may argue that there is no room left for your own creative input when reading the book upon which the movie was based, because the film director's choice of actors will always be in the way.

(6)

Humanities would decline and natural sciences development would stagnate forever, leaving us to churn butter, and all because we need a good churner of butter, instead of swinger of birches as Robert Frost would say. One can do worse than be a swinger of birches, but we wouldn't know that, if we didn't have universities.

U svim ovde navedenim primerima, kao i u ostatku korpusa, naporedna upotreba ove neodređene zamenice i ličnih zamenica odaje utisak lošeg stila, upravo zbog neprirodne promene nivoa formalnosti od neutralnog (if you do happen 
to watch the movie adaptation first) do izrazito formalnog (one may argue that there is no room left), pa opet do neutralnog (for your own creative input when reading the book). Ovakve fluktuacije u stilu i nivou formalnosti mogu se objasniti osobinama međujezika (Saville-Troike, 2005: 102), ali to svakako nije pristup u pisanju koji ima pedagošku potporu ni model u akademskim tekstovima koje studenti čitaju tokom studija.

Fluktuacije u stilu i nivou formalnosti manje su primetne kad se neodređena zamenica one ili njen prisvojni ili povratni oblik nađe sam(a) u rečenici, ali rečenice ispred i iza koriste razne oblike ličnih zamenica u funkciji ličnog metadiskursa (v. primere 7,8 i 9 ).

One should never judge a person by external appearances. We are all different. We all have flaws. We all make mistakes. It is funny how we are prone to judge others without even looking at ourselves. We tend to separate people into groups of good looking and bad looking without thinking whether that could hurt someone's feelings. Sometimes, we forget that beauty is in the eye of the beholder.

University degrees are often regarded as significant assets of one's personality. They can determine your status, respect others pay to you and influence other areas of your life.

In this digital age of progress, one could argue that every aspect of a person's life is permeated with technology's grasp. Anywhere we go, we are looking at a screen: a computer, a tablet, a phone, a tablet, even billboards.

Uprkos činjenici da unutar jedne rečenice ne dolazi do mešanja neodređene i ličnih zamenica, ove fluktuacije i dalje odaju utisak lošeg, neujednačenog stila i ukazuju na autora koji treba dosta da radi na razvoju sopstvene diskursne kompetencije.

Naposletku, veoma retko se u korpusu može naći dosledna upotreba neodređene zamenice one i njenog prisvojnog i povratnog oblika (v. primer 10). 
(10)

[...] First of all, when comparing movies to books, one might say that it is far better to watch the movie version of the same story, simply because of the more vivid imagery one gets. A movie adaptation provides people with a fantastically clear image of the depicted scenes from the story, while a book mostly provides vague images in their heads, that is - depending on the strength of one's imagination. On the other hand, this just might be the reason to read the original, book-version of the story, since it sparks creativity and develops one's imagination in the process. Furthermore, although sometimes people would rather watch the movie and rest their minds from a hard day's work, the down side to this version is that ends up watching someone else's imagination on screen. The movie version is the interpretation of only one person who has read the same book, and it may not always be the best interpretation of it. That is why reading the book on one's own gives people the freedom to experience the story like they see fit. Moreover, each time one reads a book, the imagination can produce different images and change the scene a little, while the movie is stuck with the same images forever. Next, sometimes it is not possible to read the book in one sitting, while one usually watches the movie all at once. At this day and age, when people always have to run somewhere and have no time for themselves, they are most likely to get demotivated or simply won't have time for such a luxury as reading. In such a case, watching the movie version is the perfect solution. However, when the situation is the other way around and people do have the privilege of taking the time to read, the obvious choice would be the book-version of the story, since it provides one with long-term enjoyment, it can be read for days and one can choose whether to read slowly, immersing oneself into every word, or speed up the pace to get to the interesting part of the story. On the other side, a typical movie lasts for ninety minutes and one can fast-forward or rewind the tape, but it will surely be just a short-term enjoyment, which has a limited time. Consequently, the temporally limited movies have to cut the story short in order to fit into the time-frame, so one does not get to hear the entire story as the writer has imagined it. Therefore, one gets the complete story when reading the original version, together with the long descriptive passages and the mini-scenes which are not that important to the main plot, but which enrich the story as a whole. This can have a different value to different people, though. Some might find these long passages boring and the underlying interesting story buried in the six hundred pages only comes to life in the movie adaptation. What is more, movie adaptations can benefit some, like students who did not have time to read tomorrow's obligatory reading and need just the cliffnotes to be able to follow the class. On the other hand, such a solution to their problem only promotes couch-potatoing and reduces children's literacy. 
To conclude, there are many ways to view the question of which is better - the book or its movie adaptation. Although words can be music to one's ears, sometimes a picture is worth a thousand words as well, and it all depends on one's preferance [sic].

Ovakvi sastavi u korpusu su bili retki i izuzetak od već ilustrovanog pravila o mešanju ličnih zamenica i neodređene zamenice one u generičkoj funkciji.

Ukoliko se rezultati dobijeni ovom analizom postave u širi kontekst istraživanja akademskog pisanja i autorskog prisustva, mogu se potvrditi rezultati nekih ranijih istraživanja. Na primer, Vasileva (Vassileva, 1998) u svom istraživanju autorskog prisustva u tekstovima na pet jezika (engleski, francuski, nemački, ruski i bugarski) utvrdila je da je autorska odgovornost najizraženija u tekstovima na engleskom (69\% slučajeva upotrebe zamenice $I$ ), dok tekstovi na bugarskom i ruskom, a u nekoj meri i na nemačkom, pokazuju izrazito konzervativan stil pisanja, koji podrazumeva gotovo potpuno odsustvo autorske odgovornosti (Vassileva, 1998: 166). Međutim, sastavi analizirani u ovde predstavljenom istraživanju ne pripadaju istraživačkim tekstovima, već argumentativnom tipu sastava, gde autor ima puno pravo i slobodu da iznese svoj stav o datoj temi, a ipak mestimično i nesistematično dolazi do udaljavanja od sopstvenog stava $\mathrm{u}$ bezličnu i neodređenu krajnost, upotrebom neodređene zamenice one, što se vidi i u podatku da je u ovom korpusu učestalost zamenice one gotovo ista kao učestalost zamenice $I$, iako u pogledu akademskog pisanja ove dve zamenice na potpuno različite načine realizuju prisustvo autora u tekstu. Vasileva (Vassileva, 1998: 169) kaže da je slavistička akademska tradicija prosto takva da su autori naučeni da umanje svoju ulogu u akademskom tekstu, što se dodatno postiže i upotrebom pasivnih ili bezličnih konstrukcija, čija bi se frekvencija mogla ispitati naporedo sa eksponentima ličnog metadiskursa u ovim sastavima. Stoga se može zaključiti da autori ovde analiziranih sastava ne umeju da ocene i procene kada je potrebno stvoriti distancu između sebe i publike, a kada je dozvoljeno jasno izraziti svoj stav, jer ovakve stvari očigledno nisu eksplicitno obrađivane na časovima akademskog pisanja, gde bi svaka retorička struktura mogla da bude objašnjena uz neophodno navođenje njenih diskursnih osobina.

Sem toga, jasno je da prisustvo neodređene zamenice one i njenog prisvojnog i povratnog oblika nikako ne može biti rezultat transfera osobina maternjeg jezika na pisanje na stranom jeziku, pošto u gramatičkom sistemu srpskog jezika ne postoji formalni ekvivalent ove zamenice. S druge strane, postoje razne bezlične i pasivne konstrukcije koje u velikoj meri imaju svoju paralelu $\mathrm{u}$ 
sistemu engleskog jezika, tako da se sa sigurnošću može reći da upotreba zamenice one nije posledica transfera. Drugim rečima, u pitanju je stilska interferencija zbog nedovoljno razvijene diskursne kompetencije, pa studenti ne umeju da odrede nivo formalnosti u akademskom diskursu spram tipa teksta koji pišu. Ovo može da se smatra i jednom od osobina njihovog međujezika, koji se razlikuje i od sistema maternjeg i od sistema stranog jezika koji uče.

Naposletku, svakako je potrebno uzeti u obzir i kulturne razlike između anglosaksonskog akademskog diskursa, ka kom se teži u obrazovanju ovih studenata, i slovenskog akademskog diskursa, iz kog studenti potiču (Marković, 2017: 57), te u njima potražiti korene ove osobine studentskog akademskog diskursa, koja očigledno pokazuje mešanje ova dva stila, tj. međujezičku stilsku interferenciju. U doba liberalizacije engleskog jezika i širenja normi koje uključuju i prihvataju neizvorne varijante, ne može se dati vrednosni sud da je jedan ili drugi akademski stil bolji ili prihvatljiviji, ali u svakom slučaju može se ukazati na to da mešanje ta dva stila u okviru jednog teksta, ili čak jedne rečenice, nije prihvatljivo, jer deluje nedosledno i isprekidano.

\section{ZAKLJUČAK}

Na osnovu predstavljenih rezultata korpusnog istraživanja, jasno je da visok stepen jezičke kompetencije kod studenata ne prati uvek i visok stepen diskursne kompetencije, pošto evidentno dolazi do mešanja veoma formalnog stila, koji karakteriše upotreba zamenice one, i neutralnog, a čak i neformalnog stila, koje karakteriše upotreba ličnih zamenica $I$, we, you. Rezultati istraživanja ukazuju na oblast koju očigledno treba (detaljnije) obraditi na časovima posvećenim akademskom pisanju na engleskom jeziku, te je studentima kao neizvornim govornicima ovog jezika potrebno skrenuti pažnju na ovakve diskursne greške. Tačnije, kod studenata treba razvijati svest o stepenima formalnosti i prikladnosti neformalnog, neutralnog i formalnog stila u sklopu različitih žanrova, jer se jedino ovako kod njih može razvijati diskursna kompetencija, koja vodi boljem uspehu u sklopu akademskih studija. Osim upotrebe zamenica u metadiskursnoj funkciji prisustva autora i čitaoca $u$ tekstu, neophodno je istraživati i druge teme iz ove oblasti, jer će se na taj način najpreciznije utvrditi problemi i poboljšati nastavna praksa, što je jedan od dobrih primera kako se spajaju teorijska i primenjena istraživanja sa pedagoškom i nastavnom praksom. 
Biljana Radić-Bojanić

\section{INDEFINITE PRONOUN ONE IN ACADEMIC WRITING OF NON-NATIVE SPEAKERS OF ENGLISH}

\section{Summary}

When writing academic texts, whether they are shorter essays or longer papers, non-native speakers of English tend to mix formal, neutral and informal styles. This testifies of the gap between their linguistic competence, which is in most cases fairly high, and discourse competence, which is evidently low as they do not abide by the norms of the English academic style. For that reason, this paper focuses on one aspect of style, namely the use of the indefinite pronoun one in students' essays in order to explore if students are consistent in the use of this pronoun, which signals formal written academic style. The research has relied on the analysis of a corpus of argumentative essays written by Serbian students of English language and literature who study at four university centers (East Sarajevo, Banja Luka, Belgrade and Novi Sad). The corpus consists of 325 essays with a total of cca. 70,000 words and it was analyzed in two steps: firstly, the whole corpus was analyzed for concordances of the words one, one's and oneself, and then the concordances were manually filtered whereby all cases where these three forms of the indefinite pronoun one did not have general reference were rejected. The remaining essays had around 300 occurrences of the three forms of the indefinite pronoun one, which were then analyzed in more detail in order to determine the contexts in which they occurred and in order to establish other forms of personal metadiscourse present in their vicinity. This qualitative aspect of corpus analysis has given the following results: (1) around half of the essays have just one occurrence of the pronoun one; (2) the remaining essays demonstrate a clear tendency of a mixture of formal and neutral academic styles, because students used personal pronouns we or you either in the same sentence or in the preceding or following sentences. Very few essays in the corpus have shown consistent use of the indefinite pronoun one throughout the text. These results can be understood as a signal that students' discourse competence is fairly low and that they do not use either the formal or the neutral style consistently, but instead fluctuate between these two, producing texts that do not abide by the rules of academic writing in English. In addition, this can be used as an indicator of what can be improved in an academic course which teaches academic writing in English so that students avoid making such mistakes in future.

Key words: academic writing, indefinite pronoun one, English as a foreign language, corpus analysis, interlanguage analysis. 


\section{LITERATURA}

Ädel, A. (2006). Metadiscourse in L1 and L2 English. Amsterdam/Philadelphia: John Benjamins.

Biber, D., Johansson, S., Leech, G., Conrad, S. \& Finegan, E. (1999). Longman Grammar of Spoken and Written English. Harlow: Longman.

Huddleston, R., Pullum, G. (2002). The Cambridge Grammar of the English Language. Cambridge: Cambridge University Press.

Hyland, K. (1998). Persuasion and Context: The Pragmatics of Academic Metadiscourse. Journal of Pragmatics, 30, 437-455.

Lakshmanan, U., Selinker, L. (2001). Analyzing Interlanguage: How Do We Know What Learners Know? Second Language Research, 17(4), 393-420.

Marković, J. (2017). Lični metadiskurs u pisanju kod izvornih i neizvornih govornika engleskog jezika. Filolog, VIII, 44-60.

Marković, J. (2018). Upotrebe glagola make u pisanju na engleskom jeziku kao stranom kod izvornih govornika srpskog jezika (korpusnolingvistička analiza). Zbornik Matice srpske za filologiju i lingvistiku, 61(1), 165-180.

Marković, J. (2019). Kroz prizmu kontrastivne analize međujezika. Istočno Sarajevo: Filozofski fakultet.

Quirk, R., Greenbaum, S., Leech, G. \& Svartvik, J. (1991). A Comprehensive Grammar of the English Language. London and New York: Longman.

Saville-Troike, M. (2005). Introducing Second Language Acquisition. Cambridge: Cambridge University Press.

Selinker, L. (1972). Interlanguage. International Review of Applied Linguistics, 10, 209-231.

Vassileva, I. (1998). Who Am I / Who Are We in Academic Writing? International Journal of Applied Linguistics, 8(2), 163-190. 